HStud 23 (2009)2, 247-266

DOI: 10.1556/HStud 23.2009.2.6

\title{
THE REEVALUATED PAST: THE MEMORY OF THE DUAL MONARCHY IN HUNGARIAN LITERATURE
}

\author{
MIHÁLY SZEGEDY-MASZÁK \\ Eötvös Loránd University, Budapest \\ Hungary
}

\begin{abstract}
The historical legacy of the Austro-Hungarian Monarchy remains a subject of considerable debate and particular significance in an increasingly unified Europe. Given that political unification has by no means led to any widespread consensus concerning interpretations of the half-century of European history preceding the outbreak of World War I, it may be worthwhile to consider how the memory of this geographically large and nationally and linguistically diverse state has shifted in different historical periods. This article seeks to further an understanding of the contentious legacy of the Dual Monarchy through discussion of examples from works by Hungarian authors, in particular Dezső Kosztolányi, Gyula Krúdy, and Sándor Márai.
\end{abstract}

Keywords: Hungarian literature, memory, Habsburg, Dual Monarchy, Kosztolányi, Márai, Krúdy

How is the memory of the Dual Monarchy preserved in Hungarian literature? It might be prudent to keep in mind, in searching for an answer to this question, that even among authors living under the Dual Monarchy there was little consensus. One thinks not merely of differences in political views, such as the fact that some writers accepted the state structure created in 1867 simply because they believed that the borders of historic Hungary could only be preserved within the Habsburg empire, while others urged the establishment of an independent Hungary, but also of the fact that there were those who regarded as salutary the centripetal tendencies in the intellectual life of the Monarchy, while others sought to sever Hungarian cultural life from Vienna entirely. This difference is clearly manifest in the reactions in Hungarian public opinion to the activities of Gustav Mahler when he was the musical director of the Hungarian Royal Opera between 1889 and 1891. I have written on this topic in greater detail in another context (Szegedy-Maszák, 2007). Here I intend simply to demonstrate the connections between assessments of the work of this outstanding conductor and composer and views concerning the Compromise of 1867 . 
As a student of politician, publicist, and novelist Zsigmond Kemény, Jenő Péterfy did not consider realistic the aspirations of those who sought to unite the Carpathian Basin under the rule of an independent Hungarian state. He therefore welcomed the work of the Czech-born musician in Budapest as a manifestation of the intellectual and artistic wealth of the Dual Monarchy. An essayist who was equally fluent in Hungarian and German, Péterfy saw Mahler's first-rate performances for audiences in Budapest as a substantial contribution to cultural life in Hungary. As he wrote in one of his reviews, "The fact that the performance had style was entirely his achievement. He ruled the orchestra like Alberich ruled his dwarfs" (Péterfy, 1902, vol. 2, 468).

Károly Eötvös was of a very different opinion. As an orator and writer who did a superb job as defense attorney for the Jews in the Tiszaeszlár blood libel suit, Eötvös assessed Mahler's work not on a professional basis, but rather from the perspective of those who sought Hungary's independence from the Habsburg House:

Beniczky and the Opera are lost for a time to a certain German conductor by the name of Mahler. ... When he conducted, he used six arms, six legs, and six ears, and he jumped about like a monkey in a tree. In musicianship and conducting he was not fit to tie the shoelaces of our Sándor Erkel, and yet he received three times the salary (Eötvös, 1906, 194).

Is the culture west of the Leitha part of Hungary's culture? During the half-century following the Compromise this question was inseparable from politics, while later it became a matter of interpretation. In order to determine how the retrospective assessment of the Monarchy evolved in the Hungarian literature of the interwar period, one could begin by considering the reminiscences of a writer who was born in 1900 and thus lived through the close of the era of Francis Joseph as teenager.

On the afternoon of Peter and Paul, the vacationers' idyll was at a high pitch of excitement. According to my mother and the other lady experts, every sign foretold the coming of the joyous event. It was quite certain that this very afternoon the elegant young lawyer from Budapest would speak and would ask the hand of the soft, sweet young woman from our city, who had been disappointed in her marriage. ... The suitor had brought fireworks in his suitcase from Budapest. The men had ordered a gypsy band for the evening from the city and the sharp wine and sparking water had been cooling in the pots of water since lunchtime. ... I was delighted that our summer resort would be the site of such a festive event. The deputy lieutenant of the county was taking his tea, this great man ... and if he was in a good mood he might even play the violin. ... We took a seat at the table 
THE MEMORY OF THE DUAL MONARCHY IN HUNGARIAN LITERATURE 249

when the deputy lieutenant was summoned to the garden. A county hussar stood at attention and handed him a letter.

He opened the letter and returned to the veranda. He stopped at the edge, silent. He was very pale. He had a black beard that resembled Kossuth's, and in this mournful frame his startled face shone with deathly pallor.

"What is it, Endre?" my father asked, stepping over to him.

"They've killed the heir to the throne," he replied, nervously waving his arm.

In the great stillness the gypsy band sounded so close one might have thought they were playing in the very garden. Everyone sat motionless around the table, holding their mugs decorated with onion patterns, their gestures frozen as if in a pantomime. I followed my father's gaze. He was looking towards the sky with a lost, helpless stare.

The sky was light blue, a thin, summery blue. Not a single fluff of cloud to be seen. (Márai, 1940, vol. 1, 302-304)

The passage cited is from Márai's novel Egy polgár vallomásai [Confessions of a Bourgeois], which was first published in 1934, though the text of the 1934 edition differs from the text of the third edition used here, which came into circulation in 1940 when the author was forced to make changes because of a suit filed by his former instructor György Stumpf, who raised objections to chapters touching on him (Mészáros, 2003, 528).

The excerpt is of crucial importance. It occurs towards the middle of the essentially autobiographical work, at the end of the last chapter of the first volume. The second volume deals with an entirely different world, and the differences between the two volumes are emphasized by the fact that the second volume takes up the thread of the narrative after a considerable gap in time. The hero of the story was fourteen years old when the heir to the throne was murdered, but by the beginning of the second volume he is twenty-three. The locus has also changed from Kassa to Aachen.

The passage promises the completion of foreseeable events, but the announcement of the unexpected event completely nullifies everything that has been said. No trace of the lifestyle alluded to in the beginning of the passage remains. The scene is fixed like a single frame in a film reel. The reader's knowledge that the passage deals with the disappearance of the Austro-Hungarian Monarchy gives the description particular significance.

There were writers whose lives were completely disrupted by the assassination of Francis Ferdinand. As Ferenc Herczeg, one such author, wrote, "on the day the World War began I was fifty years old and I thought I had already endured everything" (Herczeg, 1940, 341). At the turn of the century, his contemporary (though some twenty years younger) Mihály Babits had belonged to the cultural opposition. He had been one of the members of the group of writers of the periodical 
Nyugat [West] who had looked beyond Vienna for inspiration. Yet in 1939, looking back on the fall of the Monarchy, he wrote,

\begin{abstract}
one day everything suddenly changed, as if from one minute to the next, as if the windows had been shattered and the storm had come rushing in. ... The sense of security and tranquility vanished from the world. ... Everything in the second half of my life was different from what it had been in the first, and everything was worse. ... Clearly someone was mocking us. ... We now regret the loss and weep for the return of what we once hated. We are independent, but instead of feeling joy we can only tremble. (Babits, 1939, 14-16, 18-19)
\end{abstract}

The rupture of historical continuity left profound traces in the literature of the interwar period. Given space limitations, I will limit myself to three prose stories from among the large body of works that could be cited to substantiate this claim.

Dezső Kosztolányi's short novel Pacsirta [Skylark, available in English translation by Richard Aczel], conjures the world of the Dual Monarchy in a manner that merely tacitly implies its disappearance. Tibor Bonus, author of the most thorough analysis of the novel, contends that it "can be read simultaneously as irony, mockery, or serious tragedy" (Bónus, 2006, p. 138). The town in which it is set, Sárszeg, does indeed prove to be a world of squandered opportunities. The fate of Szúnyogh, the Latin instructor at the local high school, offers an example: "There was a time when he had shown prodigious talent, but in Sárszeg he had surrendered himself to the bottle and become a notorious alcoholic" (Skylark, 47). The antithesis to boorishness is urban life, representatives of which merely travel through the small town without even getting off the train, though the assessment of the personality of Miklós Ijas throws this opposition into question. It is quite possible that the "Budapest audience" to which he refers as a yardstick in his drama critiques is more a mirage than a different lifestyle rich in profound values. The craving for refinement and a wider horizon seem in themselves a provincial variant, or at least this is implied by Sárcsevits' name and his description as a "rich, laconic bachelor of independent means," the only person who sat in the reading room of the Casino: "He always read Le Figaro, and thus was generally held to be a cultivated European" (128). It is not easy to decide the extent to which this characterization, which suggests that a wider horizon necessarily means Paris and the world to the west of the Monarchy, is serious or mocking. The perspective is composite. One can hear the voice of the character on the one hand and the narrator on the other in the contention according to which, "somewhere on the banks of the Seine, from so many good intentions, from so many colors and emotions, whole buildings could be erected, whole books could be penned" (144-5). It is equally difficult to find an answer to the question concerning the extent to which the lack of interest shown by some of the members of the circle at the Casino is indifference or wisdom: 
THE MEMORY OF THE DUAL MONARCHY IN HUNGARIAN LITERATURE 251

Feri Füzes insisted on the existence of God. Olivér Hartyányi disagreed. ... With bitter, derisive words he painted a picture of ubiquitous ruin and decay ... He spoke out loud, the more to outrage his companions at table. But they paid ot the slightest notice either to him or to Feri Füzes. They were equally weary of them both (142).

Unquestionably the ambivalent assessment of the Monarchy is related to the fact that Kosztolányi had unqualified respect for 1848 as part of his family's heritage. In a volume published in 1934 he wrote of his paternal grandfather,

\begin{abstract}
During the 1848-49 War of Liberation he fought in the 27th Honvéd battalion, and he was among those who, along with the Székelys, were the last to lay down their arms. ... Three-thousand-five-hundred of them fled with Kossuth to Turkey. I can see him in Viddin in the prisoner-of-war camp shivering in the winter cold in his light canvas jacket. He has fifty piasters daily pay in his pocket, chewing on a fat piece of mutton among those suffering from cholera. He is riding in a wooden saddle and then, in a torch parade in Simla, I hear him across the distance of time as his tenor voice soars above the honvéds all singing the Szózat. ${ }^{1}$ In 1851 he is in Constantinople as the president of the local Hungarian Association. The Sublime Porte and the sultan cannot protect the refugees and an organized Austrian band of hirelings attacks them at a meeting of the Hungarian Association. They are taken as captives to Liverpool and sent from there to America.
\end{abstract}

The description of his image of his grandfather is followed by one of his own memories: "One spring day, when I was playing in the garden with my younger brother and sister, he took us by the hand and led us into the parlor, which was completely dark. He made all three of us kneel down and asked us never to forget that it was on this day that Lajos Kossuth died in a distant land" (Kosztolányi, 1933, 178-89).

The memory of 1848-49 is imprinted on the image of the Monarchy in Pacsirta. The Vajkays "cried ... at national celebrations, when all the solemn flags and speeches raised their spirits to a higher plane" (10), and when they return to their home after the departure of their daughter the images of the initial stage and the final outcome of the revolution stare down on them from the walls: "The first Hungarian cabinet; and the baldheaded Batthyány, down on his knees with his arms flung wide, waiting for the murderous bullet of his Austrian executioners" (31). The politicking overhead by the Vajkays in the restaurant is also not free of assessments of 1848 :

At the opposite end of the table the men talked politics. They spoke of state delegations, constitutional crises and of Prime Minister Kálmán Széll. 


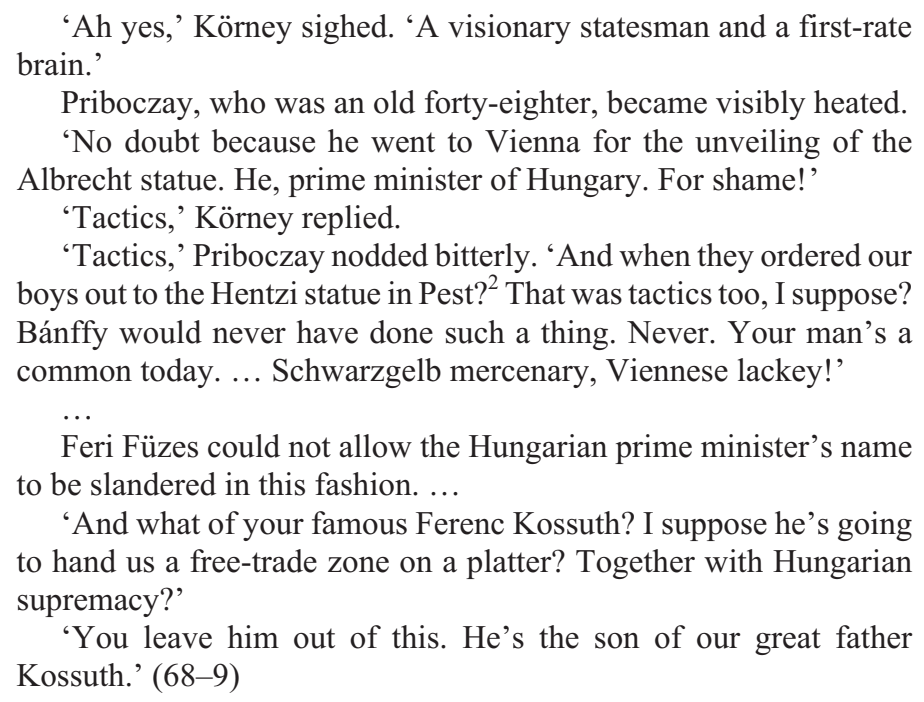

The irony in this passage is palpable. Recollection figures as a form of appropriation. The representations of 1848 and 1867 appear in the same dubious light as the debate between Feri Füzes and Olivér Hartányi concerning the existence of God. The exhaustion of the past plays a dominant role in the novel, for instance in a passage about László Ladányi, the town's representative of the independence party:

In 1849 his grandfather had been hanged from a pear tree by imperial soldiers. He would often mention this when canvassers appeared at his door with flags and torches, and he blasted them with a voice broken for good from swallowing all the nation's bitterness. He knew Ákos well, as a timid fellow who always voted for the government candidate, ... favoured compromise, all forms of compromise, including the Compromise of 1867 (134-5).

One might well ask whether there is a single aspect of the recollections of the past that is not shown in an ambivalent light by the mocking tone of the novel. Perhaps the only example is the portrait hung at the gathering place of the Leopard Society, depicting a figure of nineteenth century Hungarian cultural and political life whose stature cannot be diminished by time. The passage in question, according to which Széchenyi "looked down on what had become of his noble ideas, the debating circles and clubs he had founded to promote the refinement of polite society and social intercourse" (132), can hardly be said to lack gravity. Four years after the publication of Pacsirta, at a General Meeting of the Hungarian Writers' Association on February 2, 1930, Kosztolányi voiced ideas (which then found expression in an essay of his entitled "Lenni vagy nem lenni," or "To be or not to be," published in the February 16th edition of Nyugat) that clearly indicated the 
influence of Széchenyi on his views concerning the Hungarian nation (Kosztolányi, 1976, 300).

It would be a mistake to assume that Pacsirta offers a depiction of the world of the Monarchy from an exclusively Hungarian perspective. Sárszeg is a city of many nationalities. The violinists at the theater are German speaking, Lieutenant Werner's native tongue is Moravian, Jancsi Csinos, the leader of the gypsy band, is an "old friend of all present" (142), and particular attention is given to the owner of the Weiss and Partner fancy goods store. "Invented" characters and the "real" figures of the era remind the reader of the important role played in the popular and high culture of the time by people of non-Hungarian decent. While at the barbar, Ákos Vajkay reads the humor magazine Márton Kakas, launched in 1894 by Viktor Rákosi (1860-1923), a German who turned Hungarian. Miklós Ijas goes on walks with Ferenc Freund, "a red-faced, jovial, sharp-witted Jewish boy, who understood him, encouraged him and even dabbled a little in poetry himself" (101-2).

Sárszeg's provinciality is unambiguously manifest in its openness and even defenseless in the face of the foreign vogues of popular culture. Kosztolányi was highly critical of the genre of popular music mentioned in the novel. In his view, "it is clouded with a mild, melodious, pinkish softening of the brain" (Kosztolányi, 1972, 169). This is the closing sentence of an article he wrote on a musical comedy one year before the publication of Pacsirta. Bálint Környey encourages the Vajkay's to see The Geishas by assuring them that it is better than Shulamith. Even by today's standards, the play by Abraham Goldfaden (1840-1908) entitled Shulamith (1880) is inferior to The Geishas, which figures as a sort of caricature of the world of the novel. The music was written largely by Sidney Jones (1861-1946), the son of the conductor of the same name. He first played as a clarinetist in his father's orchestra. After writing Aladdin II, he traveled in 1891 to the United States and Australia as the musical director of the Gaiety Theater. He eventually won world renown as the composer of the music for works such as Our Family Legend (1892), The Gaiety Girl (1893), An Artist's Model (1895), A Greek Slave (1989), San Toy, The Emperor's Own (1899), My Lady Molly (1902), The Medal and the Maid (1903), See-See (1906), King of Canodia (1908), A Persian Princess (1909), A Girl from Utah (1913, and The Happy Day (1916). Of these The Geisha: A Story of a Tea House, first shown in 1896, is performed the most frequently. It was published in the same year as its first performance by Aschenberg, Hopwood and Crew in London and by Bode and C. Bock in Berlin.

As this list of titles demonstrates, Sidney Jones' operettas often transported the imaginations of members of the audiences to distant lands, such as China, Persia, and the American Wild West. The Geisha was written along similar lines. According to the narrator of Pacsirta, it was "Japan in Sárszeg". It is a loose assembly of 
individual numbers only some of which were written by Jones. Each was composed for the script written by Jimmy Davis (1853-1907), who used the penname Owen Hall. At various performances different compilations of songs were performed, usually in accordance with local circumstances. The translations of Béla Fáy and Emil Makai are quite free. One could cite the song sung by Wun-Hi (in other words Vun-Chi) as an example:

$\begin{array}{ll}\text { Chin. Chin Chinaman } & \text { Csúf, csúf csakugyan } \\ \text { Muchee muchee sad } & \text { A kínai tincs. } \\ \text { He afraid allo trade } & \text { Node volt s van-e nép, } \\ \text { Wellee wellee bad! } & \text { Hol ilyesmi nincs? } \\ \text { Noe jokem brokee-broke } & \text { Van-e föld hol a copf } \\ \text { Makeee shutee shop! } & \text { Nem ismeretes. } \\ \text { Chin Chin Chinaman, } & \text { Hip-hop csúnya copf } \\ \text { Chop, chop, chop. } & \text { Hess, hess, hess! }\end{array}$

As is well known, Kosztolányi was obsessed with the role of meaningful sound in poetry, and as a translator he endeavored to put this conviction into practice. With some exaggeration, one could say that the above cited passages seem to justify this obsession. The English text cannot be easily transplanted into Hungarian on the basis of literal meaning. The music of the passage compelled the translators to create a text with the same number of syllables wherever possible and at least a similar resonance. In his superb translation of the novel into English, Aczel cites the original text of the operetta. He could have simply retranslated the Hungarian text into English, but that would have significantly changed the sound of the passage.

The rewriting of a text necessarily constitutes a reinterpretation, situating the work in a new context. The lines following the song call attention to this:

\footnotetext{
Now it was time for the topical stanzas of the song, clumsily adapted to reflect the local political issues of the day. Sárszeg was also 'wellee, wellee bad', because it was a sea of mud, had no sewage system and its theatre ran without electricity. The audience roared.

The Lord Lieutenant ... tried to set an appropriate example by graciously condescending to beat his palms together to show that he appreciated the severe, but not unjust, criticism of the general state of affairs.

He only sprang to his feet ... when it was suggested that the Hentzi statue was also for the 'chop, chop, chop' (96).
}

The first two paragraphs of the novel clearly indicate the historical moment of the beginning of the plot. They recount events that took place on Friday, September 1, 1899. Ákos Vajkay reads articles in the paper about the second Dreyfus trial, Emperor William II's visit to Alsace-Lorraine, and communism. "There won't be another war, will there?" (56) his wife sighs. The objective tone of the 
passage clashes with Ákos' thoughts, expressed either as words spoken aloud or as part of an interior monologue. On one occasion he notes that in 1871 he was forty years-old, and later, returning from his revels, he ponders how his aging bones have been serving him for some fifty-nine years.

The relationship between the title and the text is complex. The real hero of the novel is Ákos Vajkay, as was suggested by Antal Páger, who in 1964 won the prize for the best male actor at the Cannes Film Festival for his portrayal of Ákos in the movie directed by László Ranódy. The novel depicts the senescence of the nineteenth century and the Monarchy. Mályvádi, the physics instructor at the high school, places a sparrow under a glass dome and then vacuums the air from the container. Kosztolányi, who once ended a discussion of paintings in the various museums of the world with the statement, "our skull is a cage of colorful hummingbirds" (1974, 369), might well have been familiar with the large painting by Joseph Wright, Experiment with bird and vacuum, first exhibited in the National Gallery in London in 1768, showing a rare bird, a skull, and a cage. It is certain that in the world of Pacsirta death plays an important role: "There were three coffin makers in Széchenyi Street, one after the other, and two stonemason's yards" (52). Ákos Vajkay's state of mind is described by the narrator thusly: "The last years of his life he spent increasingly in preparation for his death" (27).

One could discern a connection between the portrayal of death in the novel and two of Kosztolányi's poems. One of these was included in the volume entitled $A$ szegény kisgyermek panaszai [The Complaints of the Poor Small Child], published in 1913:

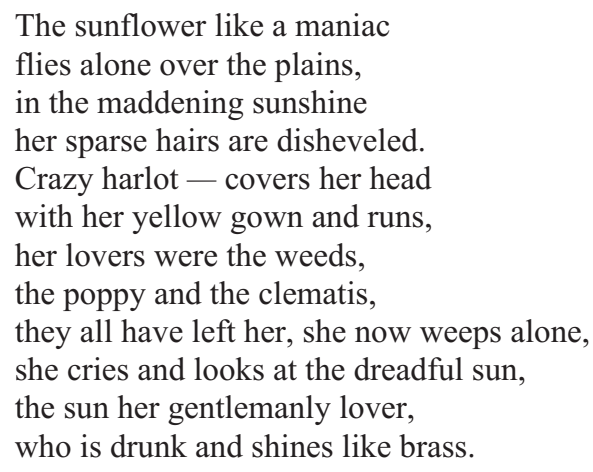

At the end of chapter seven Miklós Miklós Ijas accompanies the Vajkays to their home. After they part he looks at the garden. It is unclear whether the next sentence represents his perspective or that of the narrator: "A sunflower hung its head in the failing evening light, as if blindly searching for the sun on the ground. The sun into which it would usually stare and which was no nowhere to be found" 
(112). The other excerpt is at the end of the penultimate chapter. Pacsirta has returned to her home in Sárszeg.

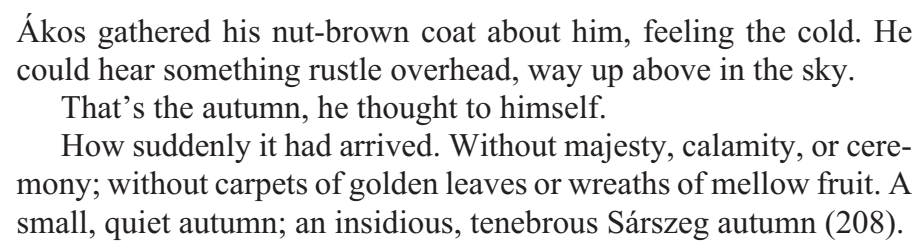

Ákos gathered his nut-brown coat about him, feeling the cold. He could hear something rustle overhead, way up above in the sky.

That's the autumn, he thought to himself.

How suddenly it had arrived. Without majesty, calamity, or ceremony; without carpets of golden leaves or wreaths of mellow fruit. A small, quiet autumn; an insidious, tenebrous Sárszeg autumn (208).

This passage in the novel seems to contradict a later poem by Kosztolányi entitled Öszi reggeli [Autumn Breakfast], written in 1929:

\author{
This is what autumn has brought. Cool fruits \\ On a glass platter. Heavy dark-emerald \\ Grapes, mighty jasper-colored pears, \\ So many rich, sparkling jewels. \\ A drop of water falls from a sturdy berry \\ And rolls away like a diamond. \\ This is splendor, merciless, elated, \\ Self-centered perfection. \\ It would be better to live. But the trees beyond \\ Beckon me with their golden hands.
}

All around him Ákos Vajkay sees the opposite of this artistic image of autumn. His internal vision is inseparable from the concentricity of the times. "Once again he was gaunt, sickly, and pale, just as he had been when he daughter had departed" (186-7). Earlier he had had oppressive dreams, but the day after the big party it is reality that comes to seem like a dream populated by the dead: "he felt he must be dreaming the whole thing, sitting among deathly shadows like a ghost" (196). The depressing effects of the vision of annihilation are mitigated only by the novel's self-referentiality. Miklós Ijas, observing the mournful return of the Vajkay's daughter, takes out his note pad to jot down the starting point of a novel, "Poor Skylark with her parents walking after midnight. Széchenyi Street. Porter” (206).

Although the novel Boldogult úrfikoromban [In My Bygone Gentlemanly Youth], published six years after Pacsirta, hardly constituted a tragedy (in the epilogue Mr. Kacskovics brings the two young people from the Szepesség, or Spišsky, region together and entrusts them with the inn called To the City of Vienna), Krúdy's novel depicts the world of the Monarchy as even more irretrievably lost. In assessing this novel it might be well to recall that its author wrote frequently about Francis Joseph, chose the son of the king as the hero of several of his works, repeatedly referred to the coronation of Charles IV, and one year after the publication of Boldogult úrfikoromban published a novel about Ferdinand I entitled $A$ festett király [The Painted King]. 
The past alluded to in the title of the novel is first referred to through mention of Mr. Kriptai's coat. Later Uncle Plac, the bankrupt lease-holder and the "Jew from the plain," relates it to Vienna and the anonymous narrator relates it to the era of the waltz. The fictitiousness of the characters is much more marked here than in Kosztolányi's novel. "The actors in this story are not people who reveal their incognito immediately upon taking the stage." It is more difficult to assess the meaning of some of the pronouncements, because they are frequently contradictory, and it is impossible to determine which ones the narrator identifies with. Even the seriousness of the narrator is open to question. "Pest never had an aboriginal population, even today the people who wind up here are just the people who happened to have the idea of coming," the "gentleman" states at the beginning of the novel. The opinion of Kacskovics's mother, mentioned at the beginning of the second chapter, seems to contradict this assertion: "After various adventures the old lady returned to her home and swore that she would never again take another step in this city where, without her knowledge, streets were given new names, new houses were built, and new stores were opened with no notification given to the old, original inhabitants in advance." Toward the end of the novel there is a sentence expressing the confrontation between natives and foreigners. It is difficult to determine whether it represents the views of Dallosi, "the notorious nighttime waiter," or the perspective of the narrator: "When all is said and done, the people of Pest have to stick together, because the foreigners can leave the city any time."

The vaguely described identities of the characters and the varying points of view make the novel less readable as a history of the times than Pacsirta. There are major differences between the two works in other ways as well. Krúdy's novel continuously reminds the reader of the capital of the empire. As examples one could mention not only the name Baron Burg, the song starting with "Ring, ring, ringerei..." or Mr. Pista's, the president's, reference to the Viennese Rothschilds, but also the fact that Mr. Vajsz was "in his youth a brewery apprentice in the brewery of old Antal Dreher" and came to Budapest to serve beer from Schwechat. In this context it is hardly surprising that he called his restaurant in Budapest To the City of Vienna. References to the 1848 Hungarian revolution are much scarcer in this novel than in Pacsirta, and frankly can be described as somewhat ambivalent. One of the actors is introduced by the narrator thusly: "A. Görgei. This was his name. He was happy if the strangers passing through thought occasionally that the A stood for Artur. Unfortunately it only stood for Alfred." An even slighter trace of memory is "the president's" reference to the paper called Egyetértés [Agreement], because the novel makes mention of only a public health advertisement by the folksong composer and pharmacist Jenő Fejér. Only the most discerning reader would remember that it was in this paper, on June 11, 1884, that Károly Eötvös nominated Lajos Kossuth as representative in the Nagyvárad electoral district. 
The reader might well believe that Boldogult úrfikoromban offers a far more favorable assessment of the Monarchy than that given in Pacsirta. The period of life (and the lifestyle) mentioned in the title, "which can no longer be seen today," is unmistakably identified with the era of Francis Joseph. Mr. Pista states that, "Everyone who survived Francis Joseph is crazy." He hints that after the disappearance of the Monarchy a different way of keeping time had come into use. "The hollow key to wind the watch will always remain popular in Hungary as long as distinguished gentlemen live in this country who prefer their father's and grandfather's pocket watches to the watches supplied by modern watchmakers with alarms."

The gravity of the appraisal is undermined by the opening lines, which make it apparent that the recollected past is a product of the imagination. "Francis Joseph was the king, and he assigned the crows and the ice flow each to their own military barracks." The opening chapter emphasizes with repetitions what Mr. Pista later makes explicit, saying "Since then, everything in the world has become chaotic." He also comments, "If I have achieved anything in my life it was due, in addition the benevolent, paternal love of our King Francis Joseph, to not having wasted my time thinking about frivolities, moustaches, moustache wax, and hair lotions." These words suggest the unlikelihood of the past, as do a number of other statements in the novel. "Under what name do you write, Mr. 'Editor'?" When Mr. Pista asks this question he is given the following answer: "I write under the name of Mrs. Edit Nagy Polkási ... because I do not wish to engage in law suits with Francis Joseph." The novel interprets the person of the ruler as an imaginary actor. "Francis Joseph issued instructions about Márton's Day ... The Jews from Pozsony took their best goose to His Majesty as a present," says a middle-aged gentleman. According to one of the numerous parenthetical comments, Tiller the military tailor says hello to the "fascia boards, the palaces and the fresh air coming from the city park, just as Francis Joseph used to do when his carriage entered Andrássy Avenue." The porter of the beer hall To the City of Vienna claims that, "In Wien nobody is surprised when a new keg is tapped because every 'Viennese kid' knows that at the same time a new twenty gallon keg is being tapped for His Majesty, the Emperor Francis Joseph, in the small restaurant that the emperor 'maintains' for his own use."

The unreliability of the narrative, which is inseparable from the humor of the novel, is augmented by the fact that while the action of Krúdy's novel is significantly shorter than that of Kosztolányi's, covering a period only slightly longer than twenty-four hours, events mentioned in the story touch on a period of several decades. In one instance there is mention of Mari Hegyesi, the actress who lived from 1861 to 1925 and who as a member of the National Theater played memorably in the roles of Portia, Hermione, Melinda, Gina from the Wild Duck, Lady Windermere, and Rose Bernd and won first prize in the competition held by 
Magyar Hirlap because according to the jury she had the most beautiful legs in Hungary. In another moment of the narrative the "editor" refers to Freud and Jenöke claims that "Tisza is in trouble". The text makes reference to a message sent by a certain Mrs. Palkonyai in February 19XX, the tobacconist mentions composer Lajos Serly's visit to North America after 1905, and there is a discussion about Vilmos Vázsonyi (1868-1926), the middleclass democrat politician who was minister of justice in 1917 and became a royalist after 1919. We are told that the poet Endre Ady and the writer Elemér Bányai are no longer alive and Mr. Pista announces that he was not a "Bolshevist". The "middle-aged gentleman" addresses the following words to Lajos Podolini and Vilma Vilmosi, who came from the Szepesség region to the capital city: "You came from that region, who knows when you will be able to go back and see the surroundings familiar to you again." The comment might indicate that the former Upper Hungary was already under foreign occupation, and perhaps was already part of another country. Miss Vilma is an "orphaned teacher" and Podolini a former assistant district administrator, because both were forced to leave their homes and occupations. It is possible, albeit by no means clear, that Imre Bori is correct in his claim that "Dorothy Day", mentioned in the novel, refers to the 1920s $(1978,237)$. The only thing that can be ascertained with confidence is that the era of Francis Joseph figures from a longer retrospective distance than in the novel by Kosztolányi.

The two works are also linked by the manner in which the operettas are depicted as paradigmatic examples of the popular culture of the cities in the Monarchy. The quotations from Jaques Offenbach's La Grande-Duchesse de Gerolstein (1867), Robert Planquette's Les Cloches de Corneville (1877) and Rip van Winkle (1882), Karl Milocker's Gasparone (1884) and Karl Zeller's Der Vogelhändler (1891) suggest that the Pest characters of Krúdy's novel keep up less with the times than the public in Sárszeg. References to more classical music remind us that such an assumption is at most one-sided. The "lovag" (knight) definitely has a refined ear. He plays not only Viennese waltzes on the piano but also excerpts from Die Entführung aus dem Serail. Mr. Pista speaks of the singing of David Ney and the tobacconist refers to the Sicilian Vespers and the works of Richard Wagner. The narrator even raises the matter of the "Eternal Melody" when he recalls the dancing of Miss Vilma. A certain parallelism is suggested with the section of Pacsirta in which Mrs. Vajkay, who remains at home while her husband is off partying, first plays the song Hullámzó Balaton tetején [On Top of the Waves of (Lake) Balaton] and then attempts to play Beethoven's op. 2 no. 1 sonata in F minor on the piano. One might be tempted to conclude that in both novels mention of the more select music comes in segments of the text that offer insight into the more profound layers of the characters' mentality.

One might offer a similar interpretation of the mention of Chopin's opus 61 polonaise fantasy in Sándor Márai's novel A gyertyák csonkig égnek [The Candles 
Burn Down to a Stub, or Embers, as it is known in the English translation by Carol Brown Janew, published in New York in 2001]. The principal character in Márai's novel, Henrik, is separated from his mother, the French countess, and his Polish friend Konrad by his lack of appreciation of music. A certain echo of Thomas Mann's works can be sensed in the way in which the novel establishes an opposition between appreciation for art and the behavior of the character. The military school near Vienna, where Henrik and Konrád were educated, was such a noted establishment in the Monarchy that it inspired Robert Musil to write his short novel Die Verwirrungen des Jünglings Törless in 1906. Musil was a student from 1894 to 1897 in the same school in the Moravian town Weisskirchen (today Hranice) that Rainer Maria Rilke attended in 1890-91. This was also the school where the hero of Joseph Roth's novel Radetzkymarsch, published in 1932, was a student. Géza Ottlik's novel Iskola a határon [School on the Border] was also about the effects of such a school. According to A gyertyák csonkig égnek, the military school considered music a form of rebellion and therefore did not allow it.

Márai's views concerning the Monarchy underwent a far more drastic change than those of Mihály Babits. A gyertyák csonkig égnek is not his first novel about the Monarchy. The action of $A$ zendülök [The Rebels, available in English translation by George Szirtes], called only Zendülök in the second edition published in 1945, takes place in May of 1918. The link between the two novels is revealed by a prediction in the last chapter of the earlier work (Márai, 1945, 315). A Zendülök portrays the lives of teenagers in the countryside, but offers a number of prophecies concerning the end of the Monarchy. When one of the principal characters visits a cobbler who has returned from the front with a bullet through his lung, for instance, the wounded veteran relates that he executed soldiers. The boy asks who these soldiers were, to which the cobbler merely responds by saying, "They were Czech officers. Traitors to the country" (34).

Writing in Vörös Újság in 1919, Márai took a position which permits us to conclude that in his view the pre-1914 conditions were uniformly unsatisfactory. Egy polgár vallomásai, however, makes no mention of this, and in a later series of articles Márai welcomed the two Vienna Awards through which Hungary regained most of the ethnically Hungarian areas lost in the 1920 Peace Treaty of Trianon. István Fried contends that Márai did this with little reflection, though given the lack of substantiation he offers for this claim his conclusion remains unpersuasive (Fried, 2007, 29). One might well ask whether there were any Hungarian writers who did not welcome the return of territories lost in the wake of the First World War. It is perhaps sufficient, to demonstrate the general approval with which these changes were met in Hungary, to cite poet Miklós Radnóti, who on August 30, 1940, wrote jubilantly in his diary, "The Vienna Award has been passed. We have gotten back 50,000 square kilometers of Transylvania, including Kolozsvár!" (Radnóti, 1989, 95) 
In 1942 Márai was elected a corresponding member of the Hungarian Academy of Sciences. He was granted official recognition, which neither Babits nor Kosztolányi were awarded, but which was granted to Ferenc Herczeg. Herczeg, author of Az élet kapuja [The Gate of Life], considered Francis Joseph's Monarchy the best possible state structure for Central Europe. Márai visited Herczeg in his home in Hüvösvölgy (a neighborhood of Budapest) prior to leaving Hungary for good in 1948.

It is a commonplace that Kosztolányi and Krúdy both had a strong influence on Márai's writing. The hunt, the key scene in A gyertyák csonkig égnek, takes place in 1899 , but the narrative distance is clearly retrospective. The last meeting between Henrik and Konrád takes place after the outbreak of the Second World War. The era of Francis Joseph is long past for both of them. Henrik's mother once danced with the king, but no one "learned what the king had said to the lady, who had come from abroad, and who had wept while dancing."

Like Pacsirta, A gyertyák csonkig égnek also touches on the multinational nature of the Monarchy, but it depicts the intermixture of various nationalities as an ideal. "It was one great family," says the narrator, "Vienna, the empire, the Hungarians, Germans, Moravians, Czechs, Serbs, Croatians, and Italians." The difference in perspective between the two friends could be attributed to the fact that one of them views the past as a closed chapter, while the other continues to live in it. "It was a world for which it was worthwhile to live and to die. That world is dead. I have nothing in common with the new one." This is Konrád's view. Henrik's can be summarized as follows, "For me that world is still alive, even though in reality it has died." The difference between the foreign and the familiar, which changes in Krúdy's work as a function of the perspectives of the characters, has been straightforward for Henrik since his childhood. In the chateau in Brittany owned by his mother's family, "when the strangers leaned over him he decided that he would rather die".

The elimination of ambiguity in A gyertyák csonkig égnek makes it something of an allegorical novel. In this it differs from the works of Kosztolányi and Krúdy. "This is the task of mankind," states Henrik's mother, and she continues her son's education by saying, "One day we have to lose those whom we love. A person who cannot cope with this is no great loss, because he is not a complete man." Henrik also believes in absolute truths, "One must endure, that is the secret." This is the lesson he deduces from his own fate, and he later uses the same argument in a discussion with Konrád: "Fate enters through the door that we have opened, and we usher fate in ahead of ourselves. ... After all, you were the one who introduced Krisztina to me."

A gyertyák csonkig égnek combines the references to the Dual Monarchy with tones of yearning for the past. This is particularly striking if we compare it with Musil's novel, The Man without Qualities, which was published in 1930 and 
which offers a satirical interpretation of the empire of Francis Joseph. In the nineteenth chapter, Ulrich receives a letter from his father, who suggests that all of 1918 should be devoted to festivities reminding the citizenry of the seventieth anniversary of the reign of the emperor of peace. Kakania is composed of ill-fitting parts and is therefore destined for dissolution. Henrik remembers a governmental structure in which everyone found his place and was very much aware of it. The contrast is accentuated by the fact that Márai held views that differed radically from those of a large segment of the Hungarian population, which assessed the conditions of the post-Compromise era from the distant perspective of the defeat of the 1848-49 War of Liberation. This heritage is palpable in Kosztolányi's Pacsirta, equivocal in Boldogult úrfikoromban, and absent in Márai's A gyertyák csonkig égnek.

Márai's novel was published in German after the Second World War in a translation by Eugen Görz under the title of Die Kerzen brennen ab. It was published in Vienna and Berlin by the Neff Verlag in 1950 and, in a revised edition, in 1954. As far as I can tell these editions met with little success. It was published by the Piper Verlag in Munich in 1999 and was a major success at the Frankfurt Book Fair. The recognition it garnered was probably due to the new translation by Christina Viragh, the new, shorter title [Die Glut], and the fact that the most influential German literary critic, Marcel Reich-Ranicki, mentioned it on television as the most interesting book at the fair.

The change in title might have been a response to the French version by Marcelle and Georges Renier. Les Braises was published in 1958 in Paris by Buchet-Chastel-Corréa, but met with little recognition in spite of the fact that the noted authors, Bernard Pingaud and Marcel Brion, reviewed it favorably in L'Express and Le Monde. The Italian version, under the title, Le braci, was published in 1998 in Milan by Adelphi and sold approximately 250,000 copies by October, 2002 (Mészáros, 58). The novel was not based on the French version, but rather was translated from the Hungarian by Marinella d'Alessandro (Mazán, 2005, 58).

According to one of Márai's Hungarian interpreters, A gyertyák csonkig égnek is one of his "least successful undertakings" (Rónay, 1998, 145). Is this conclusion contradicted by the success of the Italian and German translations? One should perhaps keep in mind that the reception of the German translation should be measured not only by the number of copies sold, and that some German papers described the novel as trashy (Kocsis, 2005, 74). Furthermore, the second German translation was in all probability a good one from the perspective of the target-language readership. Even the new title influenced its reception. Márai was undoubtedly familiar with the French translation, and one can assume that it was under the influence of this translation that he gave the name Parázs [Embers] to the play he wrote between 1960 and 1981 and published in 1982 (Márai, 1982). The short text 
differs considerably from the novel. Konrád does not merely listen to the general's monolog, but rather engages in a dialog with his host. Instead of the ninety-one-year-old Nini, the third character is an anonymous valet. The majority of translators ignored this version, which given the mention of the curtain one can assume was meant for the stage, and some may not have known of its existence.

It would be a mistake to believe that the new title "places Krisztina front and center" (Kocsis, 73), because it refers not only to the fact that toward the end of the meeting between Henrik and Konrád the husband throws the diary of his late wife "into the embers," after Konrád has told him that he does not want it to be read. The word "embers" appears considerably earlier in the novel, in the fifteenth chapter, in which the motionless guest listens to the general's monolog: "He placed his cigar, with its embers dead, on the edge of the glass plate and crossed his arms." The new title can be understood as a metaphor for an absence that becomes a decisive element in the novel. Not only does the diary, which might throw light on what took place at the hunt, remain unread, but Konrád fails to answer Henrik's questions.

Translations can be worse than originals and can also potentially be better. This is part of the nature of literature. This applies to Embers. Janeway, who moved from Great Britain to New York, used the second German translation as the basis for her translation. Translators familiar with Hungarian filed a formal written complaint against publisher, Alfred A. Knopf, for not having selected one of them to translate from the Hungarian. The translation naturally resulted in some loss. The reader had to be informed by way of explicit explanation that the words for "killing" and "embracing" in Hungarian share the same vowel sounds (ölés and ölelés). It is perhaps more significant, however, that the English text is highly readable and omits repetitions that make the Hungarian at times seem affected.

The British author Christopher Hampton wrote a two-act play by the same title based on Janeway's translation. It was performed on March 1, 2006 in the Duke of York Theater in the West End, under the direction of Michael Blakemore, the highly regarded director of works by such authors as Shakespeare, Chekhov, O'Neill, and Brecht. The success was largely due to Jeremy Irons, famous for his work on stage and screen. Irons essentially converted the text into a monologue by Henrik, suggesting that the unanswered questions had left their mark on the fates of the principal characters. By placing the general, garbed in the military uniform of the Monarchy, into the forefront, the performance suggested that the play referred to a continuity the end of which was an irreplaceable loss in history. The attentive spectator might have been aware of the irony that he was watching the play in the country the leaders of which had been instrumental in bringing an end to this continuity.

The dramatist naturally changed the sequence of some of the events, but generally he followed the text of the English version of the novel faithfully. This may 
explain why considerable emphasis was placed on a relatively minor change. "Perhaps she wished to escape from something or someone, and this someone might be me, but it might be you," Henrik says in the novel. This reference to Konrád is absent from the play, in other words it is unequivocal that the wife wanted to leave Henrik. This narrowing of the meaning is in sharp contrast to the fact that in the play the black-out of London is mentioned. The novel only makes mention of Konrád arriving from London to visit his Hungarian friend. The purpose of the addition is evident: the playwright linked it to the history of London during the Second World War and thereby brought Márai's text closer to the London theater-going public. As far as I know, some of the British spectators raised the question as to whether Konrád could be seen as a spy, who during the Second World War was working for the Allies. I would venture the contention that on the basis of the novel this interpretation is not entirely persuasive, but nor is it inconceivable.

Pacsirta and Boldogult úrfikoromban are among the major accomplishments of Hungarian narrative prose. While Kosztolányi's novel has found some readers in translation, Márai's work was more successful abroad. Pacsirta and Boldogult úrfikoromban both contain references that are difficult to understand for readers living far from Central Europe. A gyertyák csonkig égnek is easier to convert into a successful novel in another language because it mentions only aspects of the Austro-Hungarian Monarchy that are easily understood in the absence of extensive historical knowledge. It can be safely assumed that the popularity of Le braci, Die Glut, and Embers is inseparable from the favorable regard in which the Habsburg Monarchy is held today.

This is related in part to the fact that Márai's entire oeuvre is marked by gradual beautification of the receding past. At the time of his last visit to Vienna in 1973, he admitted that Schönbrunn was "more Lehár than Wagner," but in his final assessment he essentially reworded Henrik's opinion, according to which, "The Austro-Hungarian Monarchy was proof that people speaking different languages can live together in administrative and economic harmony" (Márai, 1976, 171). Is it possible that among the audience in the Duke of York Theater there were some who perceived the precursor of a united Europe in the vision of the Monarchy conjured by Henrik?

"It does not matter what happens to them abroad. What matters is what happens to them here at home," stated Kosztolányi on the question of the reception of the works of the Hungarian authors $(1976,18)$. Márai considered both Kosztolányi and Krúdy to be greater writers than he was. I happen to share this view. The extent to which the Hungarian literary world needs to heed the demands of the international marketplace, however, remains an open question, in other words the fact that works esteemed highly by the Hungarian public may raise a minor echo abroad, while works considered minor at home may meet with great success 
abroad. It is certain that assessments of the Dual Monarchy have improved over the course of recent decades, not only in Hungarian literature but also in world public opinion. This inevitably brought a change in the evaluation of works recalling the world of this now long defunct state.

\section{Notes}

1 Szózat [Appeal] is the title of a poem by 19th century Hungarian poet Mihály Vörosmarty. It became something of an unofficial Hungarian national anthem.

2 Heinrich Hentzi was an Austrian general. During the 1848-49 Revolution and War of Liberation he offered his oath of allegiance to the Hungarian cause, which he betrayed soonafter. He was court-martialed and imprisoned. When Austrian troops occupied Buda, he was appointed commander and as such ordered his artillery to fire on parts of Pest that were inhabited exclusively by civilians. He was mortally wounded during the retaking of Buda by the Hungarian army. In 1852 the Habsburg court erected a memorial statue in his honor on a major square in Buda, despite repeated protests. In 1899 it was moved to a less conspicuous place. The statue was destroyed during the liberal democratic revolution of 1918.

\section{References}

Babits, M. (1939) Keresztülkasul az életemen (Criss-Cross through My Life) (Budapest: Nyugat).

Bónus, T. (2006) A csúf másik: A saját idegenségének irodalmi antropológiájáról - Kosztolányi: Pacsirta (The Ugly Other: On the Literary Anthropology of Individual Strangeness Kosztolányi: Pacsirta) (Budapest: Ráció).

Bori, I. Krúdy Gyula (Gyula Krúdy) (Novi Sad: Forum).

Eötvös, K. (1906) Szilágyi és Káldy (Szilágyi and Káldy) (Budapest: Révai testvérek).

Fried, I. (2007) Iró esőköpenyben (Márai életének, pályájának emlékezete) (Writer in a Raincoat (Remembrance of Márai's Life and Career)) (Budapest: Helikon).

Herczeg, F. (1940) Emlékezései: A gótikus ház (Recollections: The Gothic House) (Budapest: Singer és Wolfner).

Kocsis, L. (2005) Modern nosztalgia - nosztalgikus modernség (Modern nostalgia, nostalgic modernity) in Árpád Bernáth and Attila Bombitz (eds.) Posztumusz reneszánsz: Tanulmányok Márai Sándor német nyelvü utóéletéhez (Posthumous Renaissance: Essays on Sándor Márai's Afterlife in German) (Szeged: Grimm).

Kosztolányi, D. (1933) Bölcsőtöl a koporsóig (From the Cradle to the Grave) (Budapest: Nyugat).

Kosztolányi, D. (1972) Schopenhauer operetta (Schopenhauer operetta) in Hattyú, Pál Réz (ed.) (Budapest: Szépirodalmi Kiadó).

Kosztolányi, D. (1974) Képek a képekről (Pictures of the pictures) in Pál Réz (ed.) Sötét bujócska (Dark Hide and Seek) (Budapest: Szépirodalmi Kiadó).

Kosztolányi, D. (1976) Látjátok, feleim (You Can See It, My Friends) Pál Réz (ed.) (Budapest: Szépirodalmi Kiadó).

Kosztolányi, D. (1993) Skylark, trans. Richard Aczel (London: Chatto and Windus).

Márai, S. (1940) Egy polgár vallomásai (Confessions of a Bourgeois) (Budapest: Révai).

Márai, S. (1945) Zendülök (Rebels) (Budapest: Révai).

Márai, S. (1976) Napló: 1968-1975 (Diary: 1968-1975) (Toronto: Vörösváry). 
Márai, S. (1982) Jób ... és a könyve (Job ... and His Book) (Munich: Úrváry Griff Verlag).

Mazán, V. (2005) A siker komponensei: A gyertyák csonkig égnek német nyelvü befogadásáról (Components of Success: On the Reception of A gyertyák csonkig égnek in German). In: Posztumusz reneszánsz.

Mészáros, T. (2003) Márai Sándor bibliográfia (Sándor Márai Bibliography) (Budapest: Helikon-Petőfi Irodalmi Múzeum).

Péterfy, J. (1902) Összegyüjtött munkái (Collected Works II) (Budapest: Franklin-Társulat).

Radnóti, M. (1989) Napló (Diary) (Budapest: Magvető).

Rónay, L. (1998) Márai Sándor (Sándor Márai) (Budapest: Korona).

Szegedy-Maszák, M. (2007) Szó, kép, zene: A müvészetek összehasonlitó vizsgálata (Word, Picture, Music: A Comparative Study of the Arts) (Pozsony: Kalligram). 